\title{
The partisan politics of employment protection legislation: Social democrats, Christian democrats, and the conditioning effect of unemployment
}

\author{
Reimut Zohlnhöfer ${ }^{*}$ (iD) and Linda Voigt \\ Institute of Political Science, Heidelberg University, Heidelberg, Germany \\ ${ }^{\star}$ E-mail: reimut.zohlnhoefer@ipw.uni-heidelberg.de
}

(Received 15 September 2020; revised 16 February 2021; accepted 30 March 2021; first published online 10 May 2021)

\begin{abstract}
Political parties are likely to hold differing views about employment protection legislation (EPL). While prowelfare parties could support EPL, pro-market parties might focus on labour market deregulation. In this paper, we investigate empirically whether partisan politics, especially the government participation of Social democrats and Christian democrats, matter for EPL in 21 established OECD countries from 1985 to 2019. We show that during the golden age of the welfare state, the level of EPL was much higher where Social and Christian democrats dominated the government than elsewhere. After the golden age and under conditions of high unemployment, these unconditional effects mostly disappeared. Instead, the level of unemployment conditions partisan differences. Christian democrats liberalize EPL for regular employment significantly less than other parties under high levels of unemployment. In contrast, Social democrats defend high levels of EPL for regular and temporary employment when unemployment is low. Against expectations, they even liberalize employment protection for labour market insiders more than other parties at very high levels of unemployment.
\end{abstract}

Keywords: political parties; labour law; employment protection legislation; unemployment

\section{Introduction}

Many economists have criticized employment protection legislation (EPL) for being the root cause for the dismal employment performance in continental Europe (particularly since the 1980s) and Southern Europe (especially in the crisis years after 2008) (cf. Siebert, 1997; Blanchard, 2006). At the same time, EPL can be regarded as an inexpensive way to provide employment security to potentially vulnerable groups in the labour market - an aspect that might seem particularly attractive for welfare state supporters under conditions of permanent austerity. Given these different aspects of EPL, it is plausible that political parties hold differing views about this issue. While pro-welfare parties could support EPL and try to further regulate the labour market or at least defend the current level of regulation, pro-market parties could focus on deregulation in order to incite stronger employment dynamics. Therefore, partisan differences could play an important role when it comes to regulating the labour market.

The extant literature is far from an agreement in this regard. While Potrafke (2010) does not find any partisan effects, other scholars do report that parties make a difference. For example, Algan and Cahuc (2006) use a dichotomous variable measuring the partisan composition of government and find that right-wing parties tend to relax employment protection when in government. Correspondingly, Rueda $(2005,2007)$, Siegel (2007), and Simoni and Vlandas (2020) report that left parties expand employment protection or resist liberalization. Avdagic (2013) 
corroborates that left parties generally display less propensity to deregulate EPL than right parties, although that effect is heavily dependent on the veto player constellation. This finding nicely fits with Becher's (2010) results that the partisanship of a labour minister only matters in EPL when the ideological distance between veto players is small. Aaskoven (2019) also finds conditional partisan effects, but according to his study, left parties adopt more stringent labour market regulations only under conditions of high inequality and high public debt. Somewhat similarly, Botero et al. (2004) find a positive effect of left and centre parties, although for a broad sample of countries including many developing and non-democratic states. In contrast, Heinemann (2007), distinguishing between left, centre, and right parties, finds that left, as well as right parties, deregulate labour markets more than centre parties, that is, centre parties are in favour of labour market regulation. Similarly, Huo et al. (2008) suggest that Christian democratic (CD) parties have a positive effect on the regulation of the labour market. Finally, Emmenegger (2011), employing fsQCA, finds that CD parties are weakly relevant for labour market regulation at least in some countries.

These somewhat divergent findings seem to be due to at least five drawbacks of the existing literature. First, the dependent variable of the relevant studies varies considerably. While some studies use the OECD dataset on EPL, others resort to the relevant indicators of the Economic Freedom of the World index while still, other authors have compiled data themselves. More importantly, many studies lump together regulations of regular employment and regulations for temporary or atypical work or focus on only one of these measures.

Second, even many studies that focus explicitly on partisan effects use somewhat inadequate operationalizations of the independent variable of core interest. For example, some studies only look at the partisan affiliation of the head of government or the Minister of Labour, while others only distinguish between left and right governments. If, however, Heinemann (2007), Huo et al. (2008) and Emmenegger (2011) are correct that centre parties or CDs make the decisive difference, the dichotomy between left and right parties simply misses the point. Moreover, it seems preferable to measure the cabinet seat shares of various party families in order to represent adequately their influence in a (coalition) government than simply a party family's government participation.

Third, scholars seem to assume that partisan effects remain stable over time. Pierson's (1996) argument about the 'new politics of the welfare state' suggests, however, that partisan politics could play out differently under conditions of retrenchment and liberalization compared with the era of welfare state expansion - and some of the empirical welfare state literature seems to corroborate this expectation (e.g. Ross, 2000; Kittel and Obinger, 2003; Allan and Scruggs, 2004; Kwon and Pontusson, 2010).

Fourth, reforms of EPL are comparatively rare. This poses specific problems for the (statistical) analysis, which the standard approach of analysing country-years does not deal with satisfactorily.

Fifth, potential interactions of partisan effects are only rarely investigated and some have not been considered at all yet. Surprisingly, this is also true for the interaction between EPL and unemployment ${ }^{1}$ although the economics literature suggests that policymakers should relax EPL in order to improve labour market performance.

In this paper, we seek to address these issues. More specifically, we will argue that not only Social democrats (SD), but also CDs should be advocates of EPL and will test this argument with an adequate operationalization. At the same time, we analyse the partisan influences on the level of EPL at the earliest possible point in time (1985) and on the changes over time since then independently, which allows us to test whether partisan politics have changed in the era of the 'new politics of the welfare state'. Moreover, we investigate different aspects of EPL separately, but also as a composite indicator to find out if the partisan politics of EPL differ between these items or if there are broader patterns. Methodologically, apart from running cross-section regressions for the analysis of EPL levels, we use cabinets rather than country-years as the unit of analysis as

${ }^{1}$ Simoni and Vlandas (2020) discuss how unemployment conditions the effect of trade unions on employment protection. 
suggested by Schmitt (2016) and others in order to deal with the rather small number of changes in EPL.

We proceed as follows. In the next section, we will argue theoretically, why parties should make a difference in EPL and why CDs, in particular, could play a decisive role. Moreover, we will discuss how partisan politics could have changed in the era of retrenchment and how unemployment could affect EPL reforms. Next, we will explain our empirical strategy and operationalization before we present our results. The final section concludes.

\section{Theory: Social democrats, Christian democrats, employment, and the male breadwinner}

The idea that it makes a difference policywise, which political party is in government has been discussed for decades in comparative public policy research (cf. Hibbs, 1977; Häusermann et al., 2013; Potrafke, 2017; Schmitt and Zohlnhöfer, 2019). Depending on the exact causal argument, the literature expects left parties to be more interventionist in economic affairs and more in favour of the welfare state either because the voters of these parties stand to benefit from these policies (Hibbs, 1977; Gingrich and Häusermann, 2015) or because these parties' ideologies lead them to pursue these policies (Wenzelburger and Zohlnhöfer, 2020).

The literature on the determinants of EPL in advanced democracies deduces from these expectations that social democratic parties should favour a stricter regulation of the labour market because employment protection is a way to increase the economic security of workers and employees (Rueda, 2005, 2007). If layoffs are made more difficult, the individual worker or employee, that is, the classic voter of SD parties (and left parties more generally), has to worry less that his or her main source of income runs dry unexpectedly and at short notice. In contrast, market liberal parties like conservatives should prefer little regulated labour markets, which allow employers to hire and fire workers as needed. Again, this policy preference can either be deduced from the interests of some core groups of these parties' voters like business people and managers or conservative parties' reluctance to regulate the labour market can be attributed to their belief that (labour) markets work better the less the government interferes.

While these theoretical expectations are probably rather uncontroversial, some of the literature discussed above might have too wide a concept of what a market liberal party is with regard to EPL. More specifically, Christian democrats usually are considered as bourgeois parties and are therefore subsumed as right-wing parties in the quantitative literature. This is a somewhat problematic assumption, however, because CDs have always looked for cross-class compromises and some third way between capitalism and socialism, not least because substantial parts of their electorates come from the working class (Kalyvas and van Kersbergen, 2010). Thus, they tend to be equally unsympathetic towards the unfettered operation of market forces and government intervention into the economy (Emmenegger, 2011). At the same time, CDs have been strong supporters of the welfare state, at least during the golden age (van Kersbergen, 1995; Huber and Stephens, 2001).

One issue area that used to be of prime importance for CDs is family policy (Huber and Stephens, 2001; Kalyvas and van Kersbergen, 2010). Here, they have usually advocated the traditional family model, including a division of labour with the husband as the single wage earner and a caregiving wife. This model rests upon stable employment for the male breadwinner because a loss of the husband's job would mean substantial financial problems for the whole family. Therefore, by protecting the male breadwinner's job via EPL, CDs can protect the whole family and, by the same token, stabilize the traditional family model (Emmenegger, 2011). Consequently, CDs should also be strong advocates of EPL. 
This leads to our first hypothesis:

(H1) There is a positive relationship between social democratic and Christian democratic government participation and the strictness of EPL during the golden age of the welfare state.

These expectations build on the experience of the golden years of welfare state development. Since the mid-1970s, a number of changes have occurred, however, which are argued to have transformed welfare politics, not least with regard to partisan differences (Pierson, 1996). In particular, the substantial and persistent rise of unemployment in many advanced democracies from the late 1970s onwards can be expected to be highly consequential for EPL. As unemployment failed to drop to pre-crisis levels even during booms in many countries in the 1980s and 1990 s, economists increasingly pointed to labour market rigidities in general and EPL in particular as an important reason for the dismal labour market performance of many European countries (e.g. Siebert, 1997). While the empirical evidence seems to be ambiguous, ${ }^{2}$ many economists and influential International Organizations, like the OECD (1994), advocated the view that EPL is responsible for labour market problems.

What do the rising levels of unemployment and the discourse about EPL's responsibility for that development mean for the partisan politics of EPL? For social democratic parties, unemployment poses a substantial problem. Programmatically, SDs have focused on full employment (and still do so today), not least because a high level of employment is a prerequisite for the funding of generous welfare states (e.g. Scharpf, 1991; Huber and Stephens, 1998; Huo et al., 2008; Merkel et al., 2008). Moreover, on the one hand, a substantial number of (potential) voters of SDs tend to be hit by unemployment ${ }^{3}$ and on the other hand, many voters see unemployment as a major problem governments have to attend to and perceive SD parties as particularly competent in dealing with the issue (Seeberg, 2017). Hence, SDs also have electoral motives to fight unemployment not least because even SD governments experience significant vote losses if unemployment increases (Dassonneville and Lewis-Beck, 2013; Helgason and Mérola, 2017).

While they could (try to) fight unemployment with Keynesian macroeconomic policies until the 1970s, this option became mostly unavailable from the 1980s onwards (Scharpf, 1991), as the failure of the Keynesian employment policies under French President Mitterrand in the early 1980s demonstrated. Since classic Keynesian demand management, therefore, had to be dropped from the toolbox of social democratic employment policy, even the SDs should have become more open towards the idea that unemployment needed to be fought via labour market reforms, and reforms of EPL in particular. ${ }^{4}$ Therefore, we hypothesize:

(H2a) After the golden age, the positive effect of social democratic government participation on overall EPL decreases or disappears.

Nonetheless, EPL liberalization is difficult for SDs programmatically as well as electorally. As argued above, programmatically, the protection of the core source of income for many employed people was an important goal that strict EPL promised to attain. Electorally, EPL liberalization would likely affect potential voters of SDs negatively. Employees with permanent jobs, that is,

\footnotetext{
${ }^{2}$ For example, Bradley and Stephens (2007) and Dümig (2015) find that employment protection reduces employment, while Avdagic (2015), Esping-Andersen and Regini (2000) and Baccaro and Rei (2007) do not find effects of EPL on labour market performance.

${ }^{3}$ Measuring the risk of redundancy for voters of specific party families is not easy. Nonetheless, the 'social democratic core constituency' is comprised of voters who are in a precarious position on the labour market and experience a high risk of redundancy, mostly due to their low human capital endowment (Arndt 2013). Similarly, voters who feel economically insecure (operationalized as job insecurity) are more likely to support government intervention, which, in turn, makes them much more likely to vote for SDs (Walter 2010).

${ }^{4}$ EPL liberalization was certainly not the only policy option SDs considered and adopted as a response to rising unemployment. For example, SDs may also have followed a human capital investment strategy (see Boix, 1998). Nonetheless, these strategies are complementary rather than mutually exclusive.
} 
labour market insiders, should disapprove of EPL deregulation because that policy reduces their employment security. At the same time, these labour market insiders belong to the core voters of SDs (Rueda, 2005, 2007) and these parties should try to avoid pursuing policies that are not in line with this group's preferences. Therefore, SDs should be more hesitant than other parties to liberalize EPL for regular employment. While other parties should have responded to unemployment with a liberalization of EPL also for regular employment, this pattern is less likely for SDs. Only at very high levels of unemployment, ${ }^{5}$ should SD parties consider a liberalization of EPL for regular employment at all. At that point, their programmatic goal of reducing unemployment as well as the electoral motive of demonstrating the ability to tackle one of the most important economic policy problems might override the consideration of preferences of one of their core voter groups - hence, at that point, SDs might prioritize employment over protection. Even then, though, EPL liberalization for regular employment should be less far-reaching than under other parties due to the preferences of labour market insiders. Hence, we expect:

(H3a) Even after the golden age, Social democrats have a positive effect on EPL (i.e. less liberalization or more regulation $)^{6}$ for regular employment regardless of the level of unemployment.

EPL for temporary employment could follow a different trajectory. Labour market insiders are likely to be indifferent in this respect while employed labour market outsiders should be opposed to the liberalization of atypical employment, which would make their jobs even more precarious. Although employed labour market outsiders tend to vote for SDs, they are outnumbered by insiders in these parties' electorates (see Online Appendix 1 and Bürgisser and Kurer, 2019: 45). ${ }^{7}$ Hence, their electoral relevance for SD parties is small(er). Consequently, if SDs start to believe that they have to deregulate the labour market in the face of high unemployment, they will prefer to liberalize EPL for temporary employment rather than for regular employment. However, given their traditional programmatic stance and the preferences of the outsider voters, SD will only start liberalizing when unemployment is high. Therefore, we expect:

(H4a) Even after the golden age, Social democrats have a positive effect on EPL for temporary employment (i.e. less liberalization or more regulation) when unemployment is low. This positive effect decreases with rising unemployment. ${ }^{8}$

For $C D$ parties, the situation after the golden age differs from the situation of SDs in two respects. First, full employment is much less significant programmatically for CDs compared with

\footnotetext{
${ }^{5}$ To give readers an idea of what "high unemployment" refers to: The mean of unemployment in our post-1985 sample is $7.5 \%$ with a standard deviation of 4 . Defining one standard deviation around the mean as the middle category, we arrive at the following categories: $0-5.4 \%$ low unemployment, 5.5\%-9.5\% middle category, and above $9.5 \%$ high levels of unemployment.

${ }^{6}$ One might worry that the partisan politics of (unpopular) liberalization and (popular) regulation could differ, and hence it would be unfortunate to consider both in the same model. Empirically, this worry does not seem to be justified. First, if the patterns of regulation and liberalization differed that would be due to electoral competition. Voigt and Zohlnhöfer (2020) show, however, that the partisan politics of employment protection is not conditioned by electoral competition. Second, the number of cabinets which have re-regulated the labour market is small in our sample [between 12 (temporary contracts) and 14 (regular contracts) out of 140] and the re-regulations that have occurred are mostly marginal. Focusing only on the cases of liberalizations by dropping the cases with re-regulation does not change our results significantly (results available upon request).

${ }^{7}$ The share of outsiders in Online Appendix 1 also includes the unemployed.

${ }^{8}$ One might also consider another group of labour market outsiders, namely the unemployed. This group could benefit from a deregulation of the labour market because liberalization could facilitate their entry into paid employment. It is unclear, however, whether they really have such a preference. If they expect to find a new job soon (e.g. because they believe their unemployment is of seasonal or cyclical nature), they should favour strict EPL that will protect their new employment. Moreover, this group is comparatively small and turnout among the unemployed is low (Rueda, 2007), so their relevance as part of the SD's electorate is marginal. Hence, it is unlikely that unemployed voters will move the policy stance of SDs towards EPL liberalization.
} 
SDs. CDs have never aimed at high employment rates along the lines of SDs - indeed there is a negative correlation between CD government participation and the employment rate in advanced democracies, at least until the 1990s (Dümig, 2015) - and they have tended to pursue a strategy of reducing the labour supply in response to rising unemployment. Therefore, CDs did not have an immediate programmatic incentive to respond to unemployment with EPL liberalization. Nonetheless, at some point, the problems of 'welfare without work' (Esping-Andersen, 1996) are likely to have grown so severe that even CDs may have felt compelled to incite stronger employment dynamics, at least in order to stabilize the welfare state. ${ }^{9}$ Moreover, the failure to deal with the unemployment issue, which was on top of the political agenda in several countries for many years, would have been electorally risky as it may have impaired voters' perceptions of the economic policy competence of $\mathrm{CD}$ parties. Hence, given the discourse about the relation between EPL and the labour market situation amongst economic policy experts, CDs also had reasons to respond to high unemployment by liberalizing EPL. Consequently, we expect:

(H2b) After the golden age, the positive effect (i.e., less liberalisation or more regulation) of Christian democratic government participation on overall EPL decreases or disappears.

Second, employees (insiders as well as outsiders) are less relevant electorally for CDs than for SDs because CDs tend to recruit a larger number of other voters (Online Appendix 1). Hence, from a vote-seeking perspective, CDs could have an easier time deregulating the labour market than SDs. Nonetheless, particularly labour market insiders, as the larger of the two groups, do have some strategic relevance for CDs despite their limited electoral relevance because they are important for the ability to gain majorities and for the cross-class image of CDs. Therefore, if CDs seek to liberalize EPL, they should focus on deregulating EPL for temporary employment, which is likely to cost them fewer votes.

Moreover, the focus on a liberalization of temporary employment also fits in with the programmatic positions of CDs discussed above. CDs may still want to protect the male breadwinner via EPL. From a CD perspective, the job of a family's main breadwinner deserves particular protection even, or maybe particularly, when unemployment is high. Therefore, CDs will continue to avoid the liberalization of EPL for regular employment even at levels of unemployment at which other parties will resort to liberalization of EPL even for insiders. Hence, we expect:

(H3b) After the golden age, Christian democrats have a positive effect on EPL (less liberalisation, more regulation) for regular employment when unemployment is high.

In contrast, CDs do not have a specific programmatic commitment to employment protection of temporary employment. On the contrary, the labour market participation of many labour market outsiders, like women or the young, is not considered as essential to earn their families living in the traditional family model. Hence, CDs could deem a particular protection of these jobs as unnecessary. Given that high unemployment will put pressure on these parties to liberalize and they have a strong commitment not to deregulate EPL for regular employment, while the electoral and programmatic obstacles for liberalization are negligible regarding temporary employment, we expect:

(H4b) After the golden age, Christian democrats have a negative effect on EPL (more liberalisation, less regulation) for temporary employment when unemployment is high.

\footnotetext{
${ }^{9}$ It is impossible to specify theoretically the exact level of unemployment which prompts CDs to liberalize EPL. Sometimes, the crossing of some symbolic threshold puts the issue on the agenda. For example, the German CDU/CSU adopted substantial liberalizations after the number of unemployed had increased to over 4 million in 1996 (Zohlnhöfer, 2003).
} 


\section{Method and data}

We measure our dependent variable, EPL, by the OECD's EPL indicators (OECD, 2020). The OECD operationalizes EPL along 21 basic items in 3 main areas, namely (1) the protection of regular workers against individual dismissal, (2) the regulation of temporary forms of employment (like fixed-term work contracts or temporary work agency employment), and (3) additional, specific requirements for collective dismissals (OECD, 2014). The indicators for each area measure the strictness of the regulations on a scale from 0 to 6 . Higher values indicate stricter regulation. We use three indicators as dependent variables: the two indices for EPL concerning temporary and regular contracts separately (ranging from 0 to 6) and a composite index, which is the sum of the two equally weighted individual indices (ranging from 0 to 12). We are thus able to investigate whether different politics drive the level and development of EPL for regular and atypical employment and which factors are relevant for the overall development. We refrain from including collective dismissals because the relevant data are only available from 1998 onwards.

Although there are various ways to operationalize employment protection, we decided to employ the OECD indicators, which are available for a fairly long period of time and across all established OECD countries on a yearly basis. ${ }^{10}$ Furthermore, the OECD indicator provides the possibility to distinguish between different types of employment and thus the indicator is the best available measurement for our research interest (cf. Allard, 2005, p.5). This distinction is fruitful, as the indictors develop differently (see Online Appendix 4). In general, the regulation of temporary contracts has changed substantially more often than the regulation of regular contracts. In addition, changes in one category do not always coincide with changes in another category. Finally, the composite index picks up all of these changes.

Admittedly, EPL for regular employment only changes rarely. Nonetheless, on the one hand, changes in EPL for regular employment - when they occur - are far too important to exclude from the analysis, while on the other hand, we have specific hypotheses for EPL for temporary and regular employment, respectively. Therefore, the most appropriate and transparent way to deal with these issues is to report regressions for the composite index as well as for the individual parts separately. Moreover, our cabinet-based empirical approach mitigates the problem of rare reforms somewhat, as we discuss below.

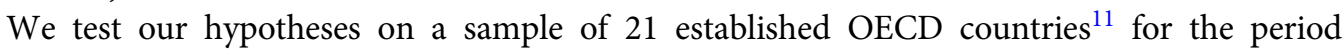
1985-2019. ${ }^{12}$

We apply a two-step strategy: In the first step, we run cross-sectional regressions with robust standard errors on the levels of EPL in the year 1985, that is, the first year for which data for our dependent variable are available. We thus seek to find out which parties have shaped EPL in the golden post-war era before the troubles of high and persistent unemployment made themselves felt. ${ }^{13}$ For each of our three dependent variables, we report two models. First, a full model, in which we include all theoretically relevant control variables in addition to the partisan composition of the government. Admittedly, these models somewhat strain the number of degrees of

\footnotetext{
${ }^{10}$ In contrast, the Economic Freedom Index only offers data for the years 1985, 1990, 1995, and from 2000 onwards. Using this index would therefore be infeasible for our cabinet-based approach.

${ }^{11}$ Australia, Austria, Belgium, Canada, Denmark, Finland, France, Germany, Greece, Ireland, Italy, Japan, the Netherlands, New Zealand, Norway, Portugal, Spain, Sweden, Switzerland, the United Kingdom, and the United States of America.

${ }^{12}$ Allard (2005) has extended the OECD data back until 1950, but only for the composite index. Therefore, we cannot use these data for our analysis.

${ }^{13}$ One might object that the golden age ended already in the mid-1970s and 1985 could thus be too late as the year of observation that reflects developments of the golden age. In contrast, we argue that the changing conditions that marked the end of the golden age needed time to be recognised by policymakers. For example, the rising unemployment in the late 1970s was perceived as cyclical and not as structural unemployment by most policymakers (Scharpf, 1991). Hence, liberalization of EPL was not considered a relevant policy option at that point. Only from the mid-1980s onwards, policy-makers considered the persistent unemployment as structural. Therefore, 1985 seems to be suitable.
} 
freedom. Therefore, we also report parsimonious models, in which we only include variables that are statistically significant at least at the $5 \%$ level.

In the second step, we run regressions on the changes in EPL in the 1985-2019 period to find out if partisan effects changed under conditions of high and persistent unemployment from the 1980s onwards. Rather than using country-years as the unit of observation, which has been the default option in the related literature, we follow recent research in using cabinets as the unit of analysis (Obinger et al., 2014; Schmitt, 2016; but already Boix, 1997). In the extant literature, cabinets are defined as governments 'with the same party composition (even if there are new elections or the prime minister changes but is of the same party)' (Boix, 1997, p.483). We slightly diverge from this definition in one respect. If a government of the exact same party composition is re-formed after an election, we still count it as a new cabinet, while the classic approach would count these two governments as one cabinet. We think our counting rule is more appropriate for two reasons. First, it slightly increases the number of cabinets and countries with highly stable governments and few changes of government (think of the UK 1979-1997 and 1997-2010) are now represented in our sample with more cabinets than is usually the case. Second, cabinets govern under and react to different and changing circumstances, which we can take into account better if we count a new cabinet after an election even if the cabinet seat shares remain stable.

As is common practice in this literature, we use the first year, in which a government has been in power for at least 6 months, as that cabinet's starting year (and similarly for the end year). If a government, therefore, comes to power in March of a given year, that particular year is defined as the start year; if a cabinet comes to power in August; however, the next year is defined as the start year. If the start and end years of a cabinet are the same, that cabinet drops out of the sample. In total, our sample consists of 140 cabinets.

There are two main reasons why we employ cabinets as the unit of analysis. First, as Schmitt (2016) has argued, cabinets are the most appropriate way to test partisan differences and this unit of observation solves a number of problems that traditional country-year settings have to struggle with. Second, the cabinet approach allows dealing with a peculiarity of our dependent variable, namely the fact that reforms of EPL are comparatively infrequent. Although the number of observations necessarily decreases when we aggregate a number of country-years to individual cabinets, at the same time the number of cases in the sample with no change drops significantly, not only in absolute numbers but also relative to the overall number of observations. Take the following example: if a cabinet that is in power for 4 years liberalizes EPL in year two, we would have one observation of change and three observations of no change in a country-year setting. In the cabinet approach, in contrast, we would only count one cabinet and observe change.

As we are interested in the liberalization or tightening of EPL in this second step of our analysis, we employ the changes of the three indices (i.e. an individual index's value in a cabinet's end year minus the value in the start year) as dependent variables. We start with basic models for each of our three indicators, in which we test unconditional partisan effects on EPL changes. Afterwards, we check whether partisan effects depended on the level of unemployment by including interaction terms. Note that each interaction term for different political parties is included in a separate model in order to avoid multicollinearity. All models are estimated using robust standard errors clustered by country as the cabinets within each country are not independent of each other (Obinger et al., 2014).

Our key explanatory variable is the partisan composition of governments. ${ }^{14}$ We use the cabinet seat shares for Social democrats and Christian democrats. In our cross-section regressions, we take the average share of cabinet seats of the respective party family in a country over the 1960-85 period, while in our cabinet regressions, we use the respective seat shares for the relevant cabinet.

\footnotetext{
${ }^{14}$ See Online Appendix 2 for the operationalization and sources of all included variables. See Online Appendix 3 for descriptive statistics of the cabinet dataset.
} 
Several control variables are included in order to consider alternative determinants of EPL. We control for unemployment rates, as EPL is often argued to trigger high levels of unemployment, which in turn should put governments under pressure to liberalize EPL. In order to test hypotheses 3 and 4, we include the interaction of CD as well as SD government participation and unemployment in our models.

We also control for GDP growth rates in our cabinet regressions and for GDP per capita in our cross-section regressions as high economic growth can be expected to make EPL liberalization less necessary. Growth rates are more appropriate for the change model as the control variable is more volatile. In addition, we include union density and strike activity in our regression models to capture the impact of trade unions on EPL reform. ${ }^{15}$ One could expect that unions will fight for the expansion and resist retrenchment of employment protection to secure their members' income. Moreover, to measure a government's institutional room to manoeuvre, we add veto player range. We hypothesize that the higher the ideological range between the veto players is, the harder it becomes to change the status quo. A government's room for manoeuvre can also be influenced by globalization. As economic globalization rises, we expect a liberalizing trend as countries may try to incite investment by offering flexible labour market regulation.

Furthermore, in our cabinet-based models, we control for cabinet duration, as is common practice in the relevant studies, because governments might have a higher chance of reforming EPL when they remain in government longer. Moreover, we also include the level of the dependent variable at the beginning of the respective cabinet to control for $\beta$-convergence.

For our cross-section regressions, we employ averages of the control variables for the years 1975-1985 (remember we use the average of the 1960-85 period for government composition). For the cabinet regressions, the control variables (with the exception of cabinet duration and the level of EPL at the beginning of the cabinet) reflect averages for the first half of the respective cabinet in order to avoid endogeneity problems (see Obinger et al., 2014). We deliberately abstain from including country dummies in our regressions for two reasons. First, including country dummies would shift the focus of our analysis away from cross-country variation, while most of the variation in our dependent variables is precisely between the countries. Moreover, using fixed effects somewhat changes what we are investigating. Paraphrasing Schmitt and Zohlnhöfer (2019, p.987) (who employ a research design that is very similar to ours), with fixed effects, we analyse the effect of changes in the partisan composition of a government in a specific country on the deviation of EPL change from the average EPL change in that country. Nevertheless, that is not what we are interested in. Second, the recent methodological literature demonstrates that fixed effects are 'not so harmless after all' (Plümper and Troeger, 2019) as a default solution in the social sciences. However, we include country fixed effects in our robustness checks. Moreover, due to the cabinet data structure, we cannot run classic time series cross-section models. In order to take the time dimension into account, we include period dummies and a time trend variable as robustness checks (see Online Appendix 2 for details).

\section{Results}

As we can see in Figure 1 (dots), the average employment protection (composite index) in our 21 OECD countries has declined almost continuously in our period of observation. ${ }^{16}$ The standard deviation also has become smaller, which means that EPL has become more similar internationally. Moreover, looking at the sub-indices shows that most of the liberalization happened in the area of temporary employment. But which role did parties play in that development? We now turn to this question.

\footnotetext{
${ }^{15}$ As there is no high correlation between the two variables, we include both.

${ }^{16}$ This trend can be regarded as corroboration of the argument about an 'institutional deregulation' of industrial relations (Baccaro and Howell, 2011).
} 


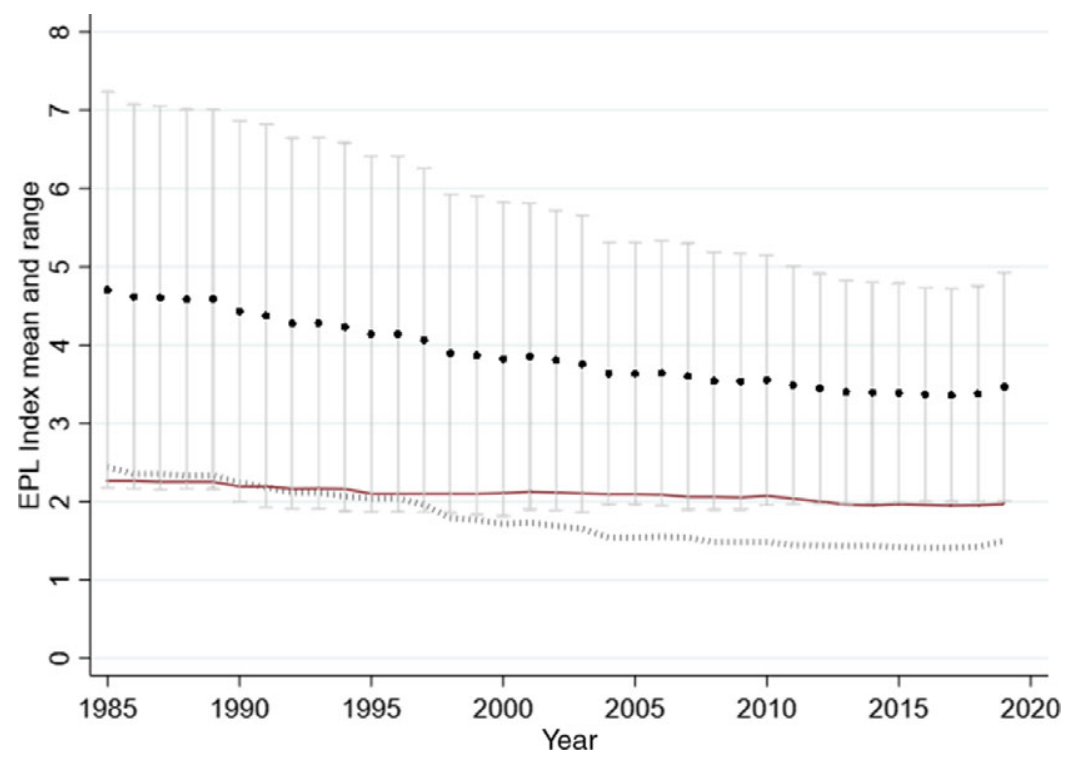

Figure 1. Development of the EPL composite index and the sub indices.

Source: Own figure based on OECD (2020) and own calculations for the index. The dots mark the EPL index mean, the whiskers illustrate the standard deviation. The dark line stands for the mean of the EPL for regular contracts; the small dotted line below shows the mean of temporary contracts.

First, we look at cross-section regressions for the levels of EPL in the year 1985, the first year for which data for our dependent variable are available. The results can be found in Table 1 .

We find the expected statistically significant positive coefficients for both social democratic and Christian democratic government participation in all six regression models. Moreover, the coefficient for SDs in power is slightly larger than that of CDs in all regressions. Thus, everything else being equal, a country entirely governed by SDs between 1960 and 1985, would have had an 8.8 points higher index score than a country without any SD government participation in that period, according to the full model for the composite index. The difference between an all-CD and a nonCD government during the same period would have been 6.4 index points (again according to model 1, everything else being equal). Therefore, the empirical evidence supports our expectation of a positive effect of Social democrats and Christian democrats (H1).

Moreover, these results are remarkably robust in a number of respects. First, we do not find noteworthy differences between the three indicators of EPL. So, SDs and CDs adopted stricter employment regulation regarding regular as well as temporary employment in the golden age. Second, results remain unchanged when we only include one party family at a time, drop control variables or try alternative operationalizations of the institutional setup. Third, jack-knife analyses essentially corroborate our findings, too. ${ }^{17}$ Finally, we checked whether our partisan effects are conditioned by unemployment. This is not the case, however (Online Appendix 5).

Regarding the control variables, results are mostly in line with expectations or insignificant. Globalization turns out to be the most important control variable: The higher economic globalization was during the 1975-85 period, the lower was the level of all three EPL indicators in 1985. This is clear corroboration of the efficiency thesis of globalization, particularly because this variable is highly robust and displays the highest beta-values in all six regressions. Similarly,

\footnotetext{
${ }^{17}$ If Italy is dropped from the full model for temporary employment and regular contracts, the coefficient for CD cabinet share falls below standard thresholds of significance $(P=.154$ and $P=.149$, respectively). The same is true for the Netherlands $(P=.130)$ and the UK $(P=.127)$ regarding regular contracts and CDs.
} 
Table 1. Cross-section models: the influence of Christian democratic and social democratic parties on employment protection legislation in 1985

\begin{tabular}{|c|c|c|c|c|c|c|}
\hline & Index (full model) & Index (parsimonious) & Temporary contracts (full) & $\begin{array}{l}\text { Temporary contracts } \\
\text { (parsimonious) }\end{array}$ & Regular contracts (full) & $\begin{array}{l}\text { Regular contracts } \\
\text { (parsimonious) }\end{array}$ \\
\hline $\begin{array}{l}\text { Christian democratic } \\
\text { cabinet shares }\end{array}$ & $\begin{array}{l}.0645^{\star \star \star} \\
(.0151)\end{array}$ & $\begin{array}{l}.0634^{\star \star \star \star} \\
(.0157)\end{array}$ & $\begin{array}{l}.0453^{\star \star \star} \\
(.0141)\end{array}$ & $\begin{array}{l}.0447^{\star \star \star} \\
(.0114)\end{array}$ & $\begin{array}{l}.0193^{\star} \\
(.0089)\end{array}$ & $\begin{array}{l}.0189 \star \star \\
(.0087)\end{array}$ \\
\hline Social democratic cabinet shares & $\begin{array}{l}.0875^{\star \star \star} \\
(.0180)\end{array}$ & $\begin{array}{l}.0860^{\star \star \star} \\
(.0161)\end{array}$ & $\begin{array}{l}.0557^{\star \star \star} \\
(.0172)\end{array}$ & $\begin{array}{l}.0553^{\star \star \star} \\
(.0119)\end{array}$ & $\begin{array}{l}.0317^{\star \star} \\
(.0108)\end{array}$ & $\begin{array}{l}.0232^{\star \star \star} \\
(.0071)\end{array}$ \\
\hline GDP per capita & $\begin{array}{l}.0002 \\
(.0002)\end{array}$ & & $\begin{array}{l}.0003 \\
(.0002)\end{array}$ & & $\begin{array}{r}-.00002 \\
(.0001)\end{array}$ & \\
\hline Unemployment & $\begin{array}{l}.3595^{\star \star} \\
(.1220)\end{array}$ & $\begin{array}{l}.2494^{\star \star \star} \\
(.0793)\end{array}$ & $\begin{array}{l}.1966^{\star \star} \\
(.0837)\end{array}$ & $\begin{array}{l}. \mathbf{1 5 2 9} \star \star \star \\
(.0506)\end{array}$ & $\begin{array}{l}.1628 \\
(.0986)\end{array}$ & \\
\hline Union density & $\begin{array}{r}-.0069 \\
(.0329)\end{array}$ & & $\begin{array}{r}-.0074 \\
(.0230)\end{array}$ & & $\begin{array}{l}.0005 \\
(.0182)\end{array}$ & \\
\hline Strikes & $\begin{array}{r}-.0022 \\
(.0019)\end{array}$ & & $\begin{aligned}-.0009 \\
(.0015)\end{aligned}$ & & $\begin{array}{r}-.0013 \\
(.0015)\end{array}$ & \\
\hline Institutions (veto player range) & $\begin{array}{l}.0430 \\
(.0326)\end{array}$ & & $\begin{array}{l}.0201 \\
(.0386)\end{array}$ & & $\begin{array}{l}.0229 \\
(.0227)\end{array}$ & \\
\hline Economic globalization & $\begin{array}{l}-.2388^{\star \star \star} \\
(.0495)\end{array}$ & $\begin{array}{l}-.1998^{\star \star \star} \\
(.0410)\end{array}$ & $\begin{array}{c}-.1561^{\star \star \star} \\
(.0321)\end{array}$ & $\begin{array}{l}-.1302^{\star \star \star} \\
(.0305)\end{array}$ & $\begin{array}{c}-.0826^{\star \star} \\
(.0302)\end{array}$ & $\begin{array}{c}-.0621^{\star \star} \\
(.0243)\end{array}$ \\
\hline Constant & $\begin{array}{c}12.9920^{\star \star \star} \\
(3.0587)\end{array}$ & $\begin{array}{l}\mathbf{1 2 . 6 1 6 2}^{\star \star \star \star} \\
(2.5094)\end{array}$ & $\begin{array}{c}7.2625^{\star \star \star} \\
(1.8902)\end{array}$ & $\begin{array}{c}\mathbf{7 . 6 1 5 6}^{\star \star \star \star} \\
(1.9758)\end{array}$ & $\begin{array}{l}\mathbf{5 . 7 2 1 1}^{\star \star} \\
(2.0931)\end{array}$ & $\begin{array}{c}\mathbf{5 . 2 7 5 8}^{\star \star \star \star} \\
(1.6084)\end{array}$ \\
\hline $\mathrm{N}$ & 21 & 21 & 21 & 21 & 21 & 21 \\
\hline Adj. $R^{2}$ & 0.5251 & 0.5737 & 0.4434 & 0.5064 & 0.1883 & 0.2616 \\
\hline
\end{tabular}

Robust standard errors in parentheses. ${ }^{* * *} P<0.01,{ }^{* *} P<0.05,{ }^{*} P<0.1$. 
Table 2. Cabinet models: effects of Christian and social democratic government participation on changes on employment protection legislation in 1985-2019

\begin{tabular}{lccc}
\hline & Index & Temporary contracts & Regular contracts \\
\hline Christian democratic cabinet shares & -.0016 & $-.0023^{\star}$ & .0001 \\
& $(.0014)$ & $(.0013)$ & $(.0006)$ \\
Social democratic cabinet shares & .0009 & .0007 & $\left(.0005^{\star}\right.$ \\
Level of EPL at the beginning of cabinet & $(.0007)$ & $(.0007)$ & $-.0376^{\star \star \star}$ \\
& $-.0827^{\star \star \star}$ & $-.1222^{\star \star \star}$ & $(.0077)$ \\
Cabinet duration & $(.0184)$ & $(.0337)$ & .0026 \\
& -.0770 & $-.0704^{\star}$ & $(.0131)$ \\
Economic growth & $(.0452)$ & $(.0406)$ & -.0023 \\
& $.0336^{\star \star}$ & $.0350^{\star \star}$ & $(.0035)$ \\
Unemployment & $(.0133)$ & $(.0128)$ & -.0053 \\
& $-.0135^{\star}$ & -.0075 & $(.0059)$ \\
Union density & $(.0069)$ & $(.0070)$ & .0008 \\
& -.0028 & $-.0041^{\star \star \star}$ & $(.0006)$ \\
Strikes & $(.0018)$ & $(.0013)$ & $-.0001^{\star}$ \\
Institutions (veto player range) & .0002 & .0003 & $(.0001)$ \\
& $(.0002)$ & $(.0002)$ & -.0012 \\
Economic globalization & -.0036 & -.0031 & $(.0013)$ \\
Constant & $(.0033)$ & $(.0031)$ & .0006 \\
$\mathrm{~N}$ & $.0038^{\star \star}$ & $.0034^{\star \star \star}$ & $(.0005)$ \\
Adj. $\mathrm{R}^{2}$ & $(.0014)$ & $(.0011)$ & .02805 \\
\hline
\end{tabular}

Robust standard errors clustered by country in parentheses. ${ }^{\star \star \star} P<0.01,{ }^{\star \star} P<0.05,{ }^{\star} P<0.1$.

unemployment goes hand in hand with stricter employment protection (although the coefficient for regular employment slightly misses statistical significance). This finding suggests that in the 1970s and 1980s, governments have responded to unemployment with tightening EPL. ${ }^{18}$ The other controls are statistically insignificant.

Next, we look at the determinants of change in EPL between 1985 and 2019 (Table 2). As expected in $\mathrm{H} 2 \mathrm{a}$ and $\mathrm{H} 2 \mathrm{~b}$, partisan effects have mostly vanished after the golden age. The only exceptions are the positive effect of SDs on EPL for regular employment and a negative effect of CDs on temporary contracts. Both coefficients are significant at the $10 \%$ level. In all other regressions, the coefficients for SD and CD cabinet shares are insignificant. ${ }^{19}$ These findings conform with our argument that under conditions of high unemployment, SDs and CDs reconsider and revise their policies. In line with $\mathrm{H} 3 \mathrm{a}$, SDs seem to focus more narrowly on labour market insiders, while they do not have a significantly positive effect on EPL for temporary employment anymore. Moreover, and as suggested in the theory section, CDs focus their liberalization attempts mostly on temporary contracts and do so even more than other parties.

Next, we include interaction terms in our models to investigate whether unemployment conditions partisan effects on various forms of EPL. ${ }^{20}$ For easier interpretation, we only provide graphical illustrations of these relations in the form of marginal effects plots; the complete numerical results can be found in Online Appendix 7.

\footnotetext{
${ }^{18}$ One might also think about reverse causality, i.e. an impact of EPL on unemployment. The fact that we have used the average unemployment rate of the 1975-1985 period to predict the level of EPL in 1985 makes this relation improbable.

${ }^{19}$ See Online Appendix 6 for the robustness check separating the two party families into two otherwise similar models. The results persist.

${ }^{20}$ As we expect different effects of CDs and SDs in the interactions, we include only one party family in the interaction models and run two otherwise similar models. We report the results with both party families in the interaction models in Online Appendix 8. Results do not change.
} 
(a) Index
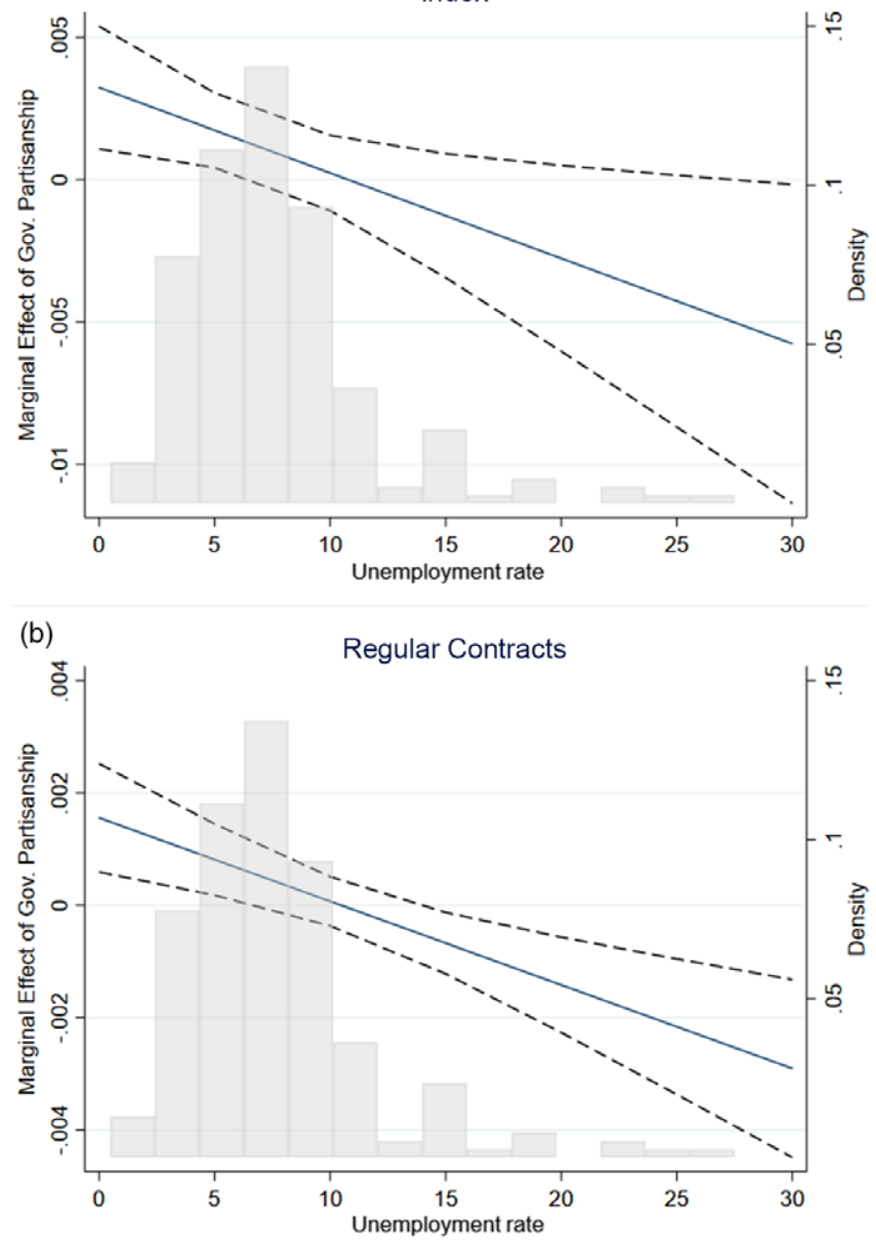

(c)

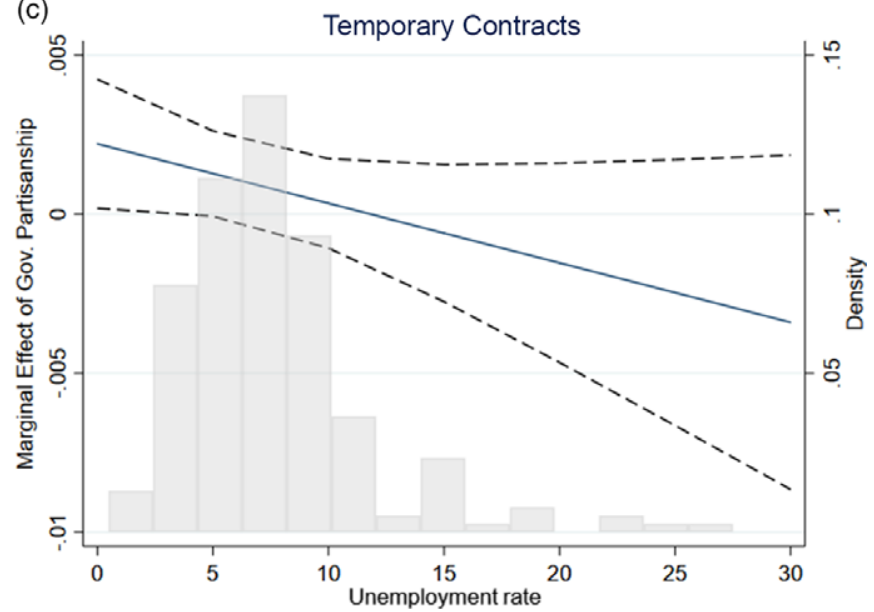

Figure 2. Conditional effect of unemployment rates on Social democratic parties' effect on EPL (a) Index, (b) Regular Contracts, (c) Temporary Contracts.

Note: The dashed lines show the 95 percent confidence intervals. 
Hypothesis 3a predicts that SD should focus on EPL for regular employment more than other parties, independent of the level of unemployment. While the above results without the interaction effect seem to corroborate this hypothesis, Figure $2 \mathrm{~b}$ does not support it anymore without limitations. Rather, only at low to medium levels of unemployment of up to $9 \%$, SDs continue to have a positive effect on EPL. This effect becomes insignificant at medium levels of unemployment and - contrary to expectations - even turns around at high levels of joblessness. Therefore, when unemployment climbs above $15 \%$ - admittedly a very high level of unemployment - SDs liberalize EPL for regular employment more than other parties. Regarding EPL for temporary employment, our hypothesis $\mathrm{H} 4 \mathrm{a}$ holds, as SDs liberalize less than other parties when unemployment is low and do not make a significant difference as unemployment rises above 7\% (Figure 2c). For the composite index, we also find the positive effect of SDs at low levels of unemployment that turns insignificant above an unemployment rate of $9 \%$ (Figure $2 \mathrm{a}$ ).

Next, we turn to Christian democrats. According to hypothesis $3 b$, we expect them to respond to rising unemployment by liberalizing EPL for regular employment significantly less than other parties in order to protect the male breadwinner. Figure $3 \mathrm{~b}$ corroborates this hypothesis. At very low levels of unemployment, CDs liberalize more than other parties. This effect becomes insignificant for medium levels of unemployment and - as expected - turns positive for unemployment rates of $10 \%$ and more. In contrast, and against hypothesis $4 \mathrm{~b}$, CDs do not exert any significant effect on EPL for temporary employment after the golden age (Figure 3c). Moreover, CD effects for the composite index are not conditioned by unemployment at all (Figure 3a).

Again, the conditional partisan effects turn out to be quite robust in a number of alternative specifications. To check for potential endogeneity, we have run robustness checks using the unemployment rate in the first year of the respective cabinet rather than the average over the first half of the cabinet's term in office. Results are virtually identical (Online Appendix 9). Hence, it is really the unemployment rate that drives policymakers' decisions to liberalize because it is impossible that the unemployment rate at the beginning of a cabinet should be affected by reforms a government adopts during its term. Likewise, results remain the same when controlling for membership in the European Union and the EU's Employment Strategy that started in 1997 (Online Appendix 10). Similarly, including a variable for different Varieties of Capitalism or welfare state regimes does not change the results (Online Appendices 11 and 12).

In the aftermath of the financial crisis of 2008, far-reaching EPL reforms were adopted, particularly in Southern Europe (Bulfone and Tassinari, 2020). Many of these reforms were responses to external pressures. To examine if these events drive our results, we included dummy variables for the financial crisis $(1=$ all cabinets in power in or after 2008, $0=$ otherwise) and for Southern Europe $(1=$ Greece, Italy, Portugal, Spain, $0=$ otherwise $)$ and included them first separately and then together. Moreover, we created a variable that specifically picks up the effects of the financial crisis in Southern Europe ( $1=$ Greece, Italy, Portugal, Spain in and after 2008, $0=$ otherwise). Controlling for these effects does not change our results either (Online Appendix 13). Moreover, we included period dummies and a time trend variable to test whether there are more general period-specific developments or a general time trend towards liberalisation. Results turn out to be robust, too (Online Appendix 14). Finally, we include country fixed effects. Unsurprisingly, our partisan variables drop below standard levels of statistical significance (Online Appendix 15). As argued above, however, including country dummies shifts the focus of the research away from what we are interested in.

Regarding control variables, we find $\beta$-convergence, that is, a process of catch-up (or catchdown) in which countries with high (low) levels of employment protection liberalize most (least or even regulate more). Similarly, countries with strong economic growth feel less of a need to deregulate temporary employment contracts (hence a positive sign). Economic globalization also keeps governments from deregulating atypical jobs, which is surprising as the coefficient thus flips its sign compared with the regressions on EPL levels in 1985. Similarly, we find that the sign of the coefficient of unemployment has turned around compared with our cross-section regressions 

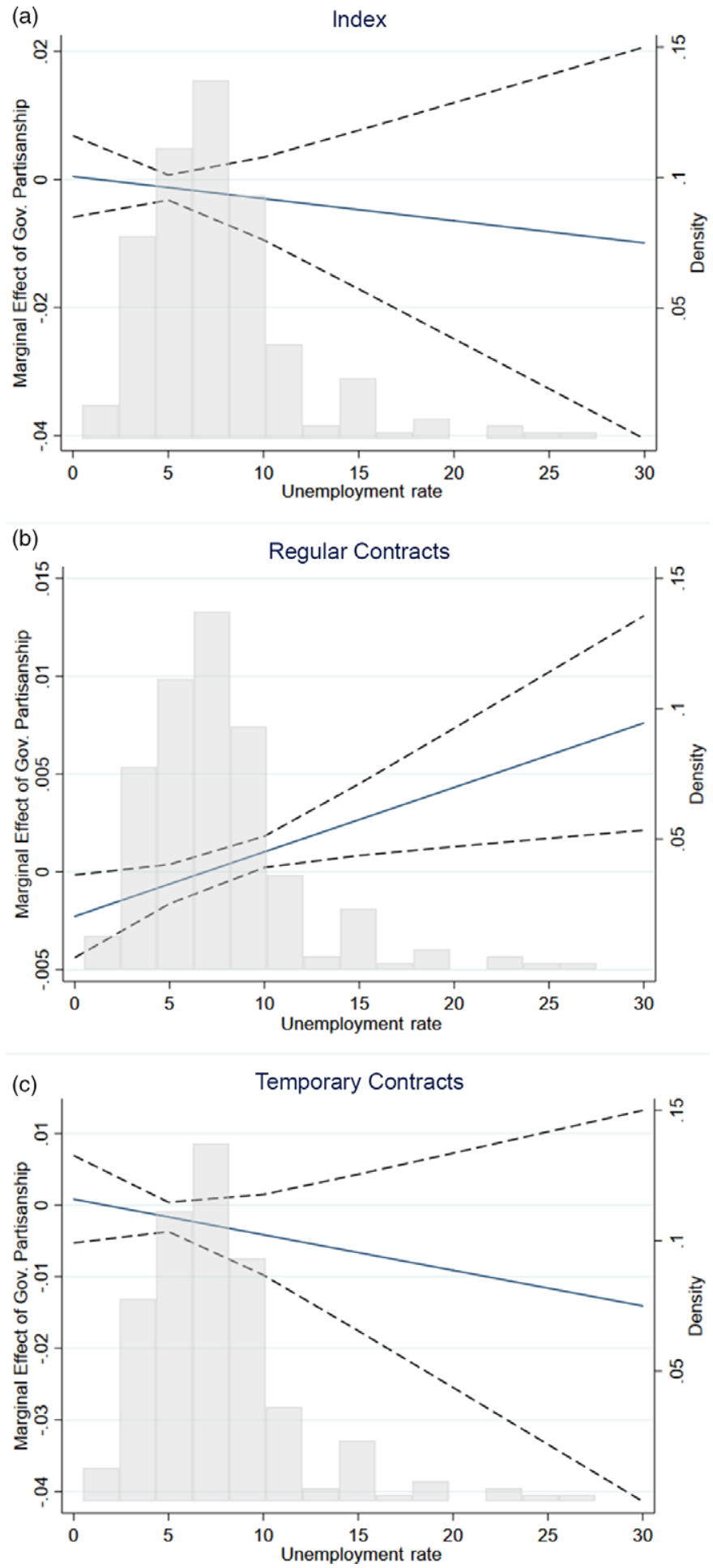

Figure 3. Conditional effect of unemployment rates on Christian democratic parties' effect on EPL (a) Index, (b) Regular Contracts, (c) Temporary Contracts.

Note: The dashed lines show the 95 percent confidence intervals. 
above, although it is only significant when we use the composite index as the dependent variable. This finding suggests that governments have abandoned EPL as a solution to the problem of unemployment and might even have started to believe that EPL is part of the problem.

Studying various aspects of EPL separately also produces interesting findings with regard to strikes and union density. For union density, we find a pattern that is consistent with an insider-outsider interpretation (Rueda, 2007; Davidsson and Emmenegger, 2013). Most importantly, even encompassing unions with a comparatively large membership do not seem to consider the interests of labour market outsiders as the coefficient of union density is significantly negative for EPL for atypical employment. ${ }^{21}$ Moreover, strikes seem to trigger a deregulation of EPL for regular employment.

\section{Conclusion}

Our empirical analysis shows that parties have strongly shaped the level of EPL during the golden age. More importantly, not only Social democrats have adopted high levels of EPL; the same is true for Christian democrats, which have been ignored in most previous contributions. Interestingly, we find these partisan differences for regular as well as temporary employment and they are very robust and are not conditioned by unemployment.

There has been a dramatic change since the mid-1980s. Unconditional partisan effects have weakened substantially or even disappeared when we look at changes in employment protection between 1985 and 2019. While we find that SDs liberalize less when it comes to regular employment, as insider-outsider theory would predict, our interaction models show that this positive SD effect is limited to situations with low unemployment. As unemployment increases, SDs stop protecting labour market insiders more than other parties and at very high levels of unemployment, we even find that they liberalize EPL for regular employment more than other parties.

The pattern for temporary employment is somewhat similar with significantly higher levels of EPL at low levels of unemployment and the vanishing of this effect as unemployment rises. Hence, SDs have also responded to high unemployment by liberalizing EPL for atypical employment. This is shown in case studies of Sweden (Murhem, 2012) and Germany (Baccaro and Benassi, 2017), for example. It is important to note, however, that SD have not liberalized EPL for temporary employment more than other parties.

So our findings somewhat go against what insider-outsider theory would predict: According to our findings SD are clearly not the agents of labour market insiders and the parties responsible for labour market dualisation. What could account for this finding?

There are at least three possible explanations. First, the electoral relevance of insider voters for SDs may differ quite substantially between countries. One could therefore argue that only SDs with a relatively large share of insider voters should have an incentive to protect these voters while SDs with a small insider voter base have no reason to differ from other parties with regard to EPL for regular employment (for a similar argument, Bürgisser and Kurer, 2019). We have empirically tested this possibility. The results in Online Appendix 17 are not particularly conclusive, however, probably due to the lower number of cases. ${ }^{22}$ On the one hand, the result that SDs with many

\footnotetext{
${ }^{21}$ On the basis of comparative case studies, Rathgeb (2018) has recently argued that encompassing trade unions advocate a better protection also for outsiders. Our results suggest that his findings cannot be generalized. Note, however, that his argument is more complex because he predicts encompassing trade unions to only be successful if they are confronted with weak governments. Testing this argument in full is beyond the scope of this paper. Nevertheless, we investigated if the conditioning effect of unemployment on partisan effects on EPL differs between countries with encompassing and non-encompassing unions. This seems to be the case. We find the conditioning effect of unemployment only in countries with weak trade unions (Online Appendix 16).

${ }^{22}$ Since data on the electoral relevance of insiders and outsiders for individual parties are not available for many cabinets as we rely on ESS waves 1-9, the number of cases declines dramatically. Furthermore, by splitting the sample into cases with high and low relevance of insider voters, the number of cases drops even further.
} 
insider voters liberalize EPL for regular employment less at medium levels of unemployment could be regarded as corroboration of the argument that the composition of the electorate matters. On the other hand, however, this argument is difficult to square with the finding that SDs with few outsider voters liberalize EPL for regular employment more than everybody else at medium levels of unemployment. Moreover, all other marginal effects plots suggest that the composition of the electorates of SDs does not matter. ${ }^{23}$

Indeed, Bulfone and Tassinari (2020), in their comparative case study on labour market reforms and electoral dynamics in Southern Europe, show that simply focusing on the most recent composition of a party's electorate might be too simplistic. Instead, these authors suggest that parties that felt compelled to liberalize the labour market have chosen reform strategies that sought to exempt different groups for electoral reasons. While Portugal's PS, for example, initially aimed at limiting liberalisation for their insider voters, the Italian Partito Democratico under Matteo Renzi embraced a liberalisation agenda (see also Picot and Tassinari, 2017), which sought to create what Bulfone and Tassinari (2020, p.6) call a 'centrist pro-EU coalition', that is, a voter coalition that includes managers, sociocultural and technical professionals, non-unionized private-sector workers, and highly skilled atypical workers and which therefore relied much less on labour market insiders. Hence, 'reform strategies are not only shaped by the extant composition of parties' electorates and by the imperative of protecting or retaining the support of groups that are preserves of a given party family ( . . . . They can also serve the function of constructing or consolidating a new social bloc by attracting support from groups contested amongst different party families (... )' (Bulfone and Tassinari, 2020, p.5). Therefore, although further research is clearly needed in this regard, at this point, we cannot argue that the electoral relevance of insider voters for SDs solves our puzzle.

Second, a Nixon-goes-to-China-logic might be at play (Ross, 2000). SDs are usually perceived as owning the issue of employment policy and are, therefore, seen as competent in this issue area. Therefore, their core voters could have believed that, if SDs (who are known to prefer strict EPL) start liberalizing under conditions of high unemployment, a liberalisation would really be necessary. That could have facilitated EPL deregulation for SDs while the prospect of being punished electorally for labour market liberalisation may have kept market liberal parties from deregulating more than SDs. The German example is instructive to evaluate this argument. While experimental evidence corroborates the Nixon-goes-to-China logic for an individual EPL liberalisation in Germany (Sulitzeanu-Kenan and Zohlnhöfer, 2019), labour market deregulation is not just a one-off reform. If, however, SDs continue to liberalize, voters might have second thoughts about their policy expectations and start punishing SDs electorally (Arndt, 2013), as the SPD has experienced after its labour market reforms in the early 2000s (Schwander and Manow, 2017).

Of course, SDs might still have believed that they are sheltered from voter wrath about liberalisation when adopting the reforms. But even if that were the case, that would only mean that SDs have an advantage in getting away with the reforms, but they should still not have a preference for those reforms in the first place. So the Nixon-goes-to-China logic cannot explain why our findings go somewhat against expectations, either.

This leads to our third point. From a policy-seeking perspective, unemployment is a highpriority policy problem for SDs, because a good employment performance is vital for achieving many important social democratic goals, most importantly the funding of generous welfare states. SDs might thus have considered the liberalisation of EPL a suitable means to improve the employment performance under these specific circumstances. Hence, they might have been willing to burden parts of their core voters in order to attain a major programmatic goal. This was not only the rationale behind the German and Swedish reforms alluded to above, but also behind the Spanish 1994 labour market reform, which at least aimed at liberalizing employment protection

\footnotetext{
${ }^{23}$ Similarly, the result that CDs with a low share of insider voters produce higher EPL for regular employment (Online Appendix 17) is also difficult to reconcile with the argument about the relevance of the composition of parties' electorates.
} 
also for insiders (although with limited success; cf. Dubin and Hopkin, n.d.; Rueda, 2007) in view of unemployment far above $20 \%$.

The programmatic shift of SDs towards more liberal EPL to improve the labour market situation is not only visible in the reforms they have enacted, however. At least as relevant are the reforms that these parties have failed to adopt. In both, Spain and Portugal, for example, due to fears of the economic consequences, the SD-led governments of Pedro Sánchez and António Costa refrained from revoking the significant EPL liberalisations their bourgeois predecessors had enacted (Bulfone and Tassinari, 2020). Similarly, despite some marginal re-regulations, the British Labour Party did not even try to reverse the liberalisation of the labour market upon its arrival to power in 1997 (Glyn and Wood, 2001; Merkel et al., 2008). Other examples could be added.

Hence, although further research is clearly needed in this regard, too, it might seem that SDs may have moderated their preference for strict employment protection at least during periods of high unemployment, mostly to improve employment dynamics. At the same time, in some cases, SDs have sought to compensate voters (and trade unions) for liberal labour markets via more generous unemployment benefits (Simoni and Vlandas, 2020). This, of course, is the basic idea of the Danish flexicurity system, but similar compensations have also occurred in recent Italian reforms (Picot and Tassinari, 2017).

So far, we have found that SDs are not responsible for labour market dualisation in the form of liberalisation of protection for atypical employment and continuing strict EPL for regular employment. But who is? Our results suggest that Christian democrats are a likely candidate. Given the important programmatic preference to protect the traditional male breadwinner model, these parties liberalized EPL for regular employment (i.e. for jobs that are typically held by male breadwinners) significantly less than everybody else. To make up for this lack of liberalisation of the insider segment of the labour market, these parties focussed on the deregulation of atypical employment. Consequently, we find an unconditional negative effect of CD government participation for EPL for temporary employment. While the interaction effect does not become significant in our main models, there is case study evidence that indeed high unemployment triggered the liberalisation of EPL for atypical employment under CD governments. Take the German case as an example (cf. Zohlnhöfer, 2003): The CDU/CSU-led governments of the 1980s and 1990s initially only very moderately deregulated EPL and focused their liberalizing attempts entirely on atypical employment. In view of record-breaking levels of unemployment in the mid-1990s, however, liberalization was substantially intensified but again remained confined to EPL for temporary employment.

Based on our findings, future research should focus on two areas. First, scholars need to investigate what kept SD from prioritizing insider preferences in the way insider-outsider theory predicts. Second, scholars should focus more on the role of Christian democrats in the process of labour market dualization than has been the case so far. Both approaches promise to further improve our understanding of the liberalisation of employment protection in the past 35 years.

Acknowledgement. We would like to thank Fabian Engler, Philipp Mai, César Colino, and three anonymous reviewers for helpful comments as well as Jonas Schmitt for research assistance. Funding of the German Research Foundation (ZO 126/5-1) is gratefully acknowledged.

Supplementary Material. To view supplementary material for this article, please visit https://doi.org/10.1017/ S1755773921000114.

\section{References}

Aaskoven, L. (2019), 'Redistributing under fiscal constraint: partisanship, debt, inequality and labour market regulation', Journal of Public Policy 39(3): 423-441.

Allan, J.P. and L. Scruggs (2004), 'Political Partisanship and Welfare State Reform in Advanced Industrial Societies', American Journal of Political Science 48(3): 496-512.

Algan, Y. and P. Cahuc (2006), 'Job Protection: The Macho Hypothesis', Oxford Review of Economic Policy 22(3): 390-410. Allard, G. (2005), Measuring job security over time: In search of a historical indicator for EPL (employment protection legislation), IE Working Paper, WP05-17, Madrid, Instituto de Empresa Business School. 
Arndt, C. (2013), The Electoral Consequences of Third Way Welfare State Reforms, Amsterdam: Amsterdam UP.

Avdagic, S. (2013), 'Partisanship, political constraints, and employment protection reforms in an era of austerity', European Political Science Review 5(3): 431-455.

Avdagic, S. (2015), 'Does Deregulation Work? Reassessing the Unemployment Effects of Employment Protection', British Journal of Industrial Relations 53(1): 6-26.

Baccaro, L. and C. Benassi (2017), 'Throwing out the Ballast: Growth Models and the Liberalization of German Industrial Relations', Socio-Economic Review 15(1): 85-115.

Baccaro, L. and C. Howell (2011), 'A Common Neoliberal Trajectory: The Transformation of Industrial Relations in Advanced Capitalism', Politics \& Society 39(4): 521-563.

Baccaro, L. and D. Rei (2007), 'Institutional Determinants of Unemployment in OECD Countries: does the Deregulatory View Hold Water?', International Organization 61(3): 527-569.

Becher, M. (2010), 'Constraining Ministerial Power: The Impact of Veto Players on Labor Market Reforms in Industrial Democracies, 1973-2000', Comparative Political Studies 43(1): 33-60.

Blanchard, O. (2006), 'European unemployment: the evolution of facts and ideas', Economic Policy 21(45): 5-59.

Boix, C. (1997), 'Privatizing the Public Business Sector in the Eighties: Economic Performance, Partisan Responses and Divided Governments', British Journal of Political Science 27(4): 473-496.

Boix, C. (1998), Political Parties, Growth and Equality, Cambridge: Cambridge UP.

Botero, J.C., S. Djankov, R. La Porta, F. Lopez-de-Silanes and A. Shleifer (2004), 'The Regulation of Labor', Quarterly Journal of Economics 119(4): 1339-1382.

Bradley, D.H. and J.D. Stephens (2007), 'Employment Performance in OECD Countries. A Test of Neoliberal and Institutionalist Hypotheses', Comparative Political Studies 40(12): 1486-1510.

Bulfone, F. and A. Tassinari (2020), 'Under Pressure. Economic Constraints, Electoral Politics and Labour Market Reforms in Southern Europe in the Decade of the Great Recession', European Journal of Political Research, online first, doi: 10.1111/ 1475-6765.12414.

Bürgisser, R. and T. Kurer (2019), Insider-Outsider Representation and Social Democratic Labor Market Policy. SocioEconomic Review, online first, https://doi.org/10.1093/ser/mwz040.

Dassonneville, R. and M.S. Lewis-Beck (2013), 'Economic Policy Voting and Incumbency: Unemployment in Western Europe', Political Science Research and Methods 1(1): 53-66.

Davidsson, J.B. and P. Emmenegger (2013), 'Defending the organisation, not the members: Unions and the reform of job security legislation in Western Europe', European Journal of Political Research 52(3): 339-363.

Dubin, K. and J. Hopkin (n.d.), Flexibility for Some, Security for Others: The Politics of Welfare and Employment in Spain, unpublished manuscript, available at http://personal.lse.ac.uk/hopkin/DubinHopkinFinal2013.pdf

Dümig, K. (2015), Politik und Arbeitsmarktperformanz. Eine quantitative Analyse von 21 etablierten OECD-Ländern, BadenBaden: Nomos.

Emmenegger, P. (2011), 'Job security regulations in Western democracies: A fuzzy set analysis', European Journal of Political Research 50(3): 336-364.

Esping-Andersen G. and M. Regini eds. (2000), in Why Deregulate Labour Markets? Oxford: Oxford UP.

Esping-Andersen, G. (1996), Welfare States Without Work: The Impasse of Labour Shedding and Familialism in Continental European Social Policy, in G. Esping-Andersen (ed.), Welfare States in Transition. National Adaptations in Global Economies. London/Thousand Oaks/New Delhi: Sage, pp. 66-87.

Gingrich, J. and S. Häusermann (2015), 'The decline of the working-class vote, the reconfiguration of the welfare support coalition and consequences for the welfare state', Journal of European Social Policy 25(1): 50-75.

Glyn, A. and S. Wood (2001), 'Economic Policy under New Labour: How Social Democratic is the Blair Government?', Political Quarterly 72(1): 50-66.

Häusermann, S., G. Picot and D. Geering (2013), 'Review Article: Rethinking Party Politics and the Welfare State - Recent Advances in the Literature', British Journal of Political Science 43(1): 221-240.

Heinemann, F. (2007), The Drivers of Deregulation in the Era of Globalization, in P. Bernholz and R. Vaubel (eds.), Political Competition and Economic Regulation. New York: Routledge. pp. 245-266.

Helgason, A.F. and V. Mérola (2017), 'Employment Insecurity, Incumbent Partisanship, and Voting Behavior in Comparative Perspective', Comparative Political Studies 50(11): 1489-1523.

Hibbs, D.A. (1977), 'Political Parties and Macroeconomic Policy', American Political Science Review 71(4): $1467-1487$.

Huber, E. and J.D. Stephens (2001), Development and Crisis of the Welfare State., Chicago/London: Chicago UP.

Huber, E. and J. D. Stephens (1998), 'Internationalization and the social democratic model. Crisis and future prospects', Comparative Political Studies 31(3): 353-397.

Huo, J., M. Nelson and J.D. Stephens (2008), 'Decommodification and activation in social democratic policy: resolving the paradox', Journal of European Social Policy 18(1): 5-20.

Kalyvas, S. and K. van Kersbergen (2010), 'Christian Democracy', Annual Review of Political Science 13, 183-209.

Kittel, B. and H. Obinger (2003), 'Political Parties, Institutions, and the Dynamics of Social Expenditure in Times of Austerity', Journal of European Public Policy 10(1): 20-45. 
Kwon, H.Y. and J. Pontusson (2010), 'Globalization, Labour Power and Partisan Politics Revisited', Socio-Economic Review 8(2): 251-281.

Merkel, W., A. Petring, C. Henkes and C. Egle (2008), Social Democracy in Power: The Capacity to Reform, London/New York: Routledge.

Murhem, S. (2012), 'Security and change: The Swedish model and employment protection 1995-2010', Economic and Industrial Democracy 34(4): 621-636.

Obinger, H., C. Schmitt and R. Zohlnhöfer (2014), 'Partisan Politics and Privatization in OECD Countries', Comparative Political Studies 47(9): 1294-1323.

OECD (1994), The OECD Jobs Study, Paris: OECD.

OECD (2014), Calculating Summary Indicators of EPL Strictness: Methodology. Available through: www.oecd.org/els/emp/ EPL-Methodology.pdf [Accessed 10/10/2019].

OECD (2020), OECD Indicators of Employment Protection. Available through: https://www.oecd.org/els/emp/ oecdindicatorsofemploymentprotection.htm [Accessed 07/12/2020].

Picot, G. and A. Tassinari (2017), 'All of one kind? Labour market reforms under austerity in Italy and Spain', Socio-Economic Review 15(2): 461-482.

Pierson, P. (1996), 'The New Politics of the Welfare State', World Politics 48(2): 143-179.

Plïmper, T. and V.E. Troeger (2019), 'Not so Harmless After All: The Fixed-Effects Model', Political Analysis 27(1): 21-45.

Potrafke, N. (2010), 'Labor Market Deregulation and Globalization: Empirical Evidence from OECD Countries', Review of World Economics 146(3): 545-571.

Potrafke, N. (2017), 'Partisan Politics: The Empirical Evidence from OECD Panel Studies', Journal of Comparative Economics 45(4): 712-750.

Rathgeb, P. (2018), Strong Governments, Precarious Workers: Labor Market Policy in the Era of Liberalization, Ithaca: Cornell UP.

Ross, F. (2000), “Beyond Left and Right”: The New Partisan Politics of Welfare', Governance 13(2): 155-183.

Rueda, D. (2005), 'Insider-Outsider Politics in Industrialized Democracies: The Challenge to Social Democratic Parties', American Political Science Review 99(1): 61-74.

Rueda, D. (2007), Social Democracy Inside Out: Partisanship and Labor Market Policy in Advanced Industrialized Democracies, Oxford: Oxford UP.

Scharpf, F.W. (1991), Crisis and Choice in European Social Democracy, Ithaca, New York: Cornell UP.

Schmitt, C. (2016), 'Panel Data Analysis and Partisan Variables: How Periodization Does Influence Partisan Effects', Journal of European Public Policy 23(10): 1442-1459.

Schmitt, C. and R. Zohlnhöfer (2019), 'Partisan Differences and the Interventionist State in Advanced Democracies', SocioEconomic Review 17(4): 969-992.

Schwander, H. and P. Manow (2017), "Modernize and Die'? German social democracy and the electoral consequences of the Agenda 2010', Socio-Economic Review 15(1): 117-134.

Seeberg, H.B. (2017), 'How Stable Is Political Parties' Issue Ownership? A Cross-Time, Cross-National Analysis', Political Studies 65(2): 475-492.

Siebert, H. (1997), 'Labor Market Rigidities: At the Root of Unemployment in Europe', Journal of Economic Perspectives 11(3): 37-54.

Siegel, N.A. (2007), Moving beyond Expenditure Accounts: The Changing Contours of the Regulatory State, 1980-2003, in: F.G. Castles (ed.), The Disappearing State? Retrenchment Realities in an Age of Globalisation. Cheltenham: Edward Elgar, pp. 245-272.

Simoni, M. and T. Vlandas, (2020), Labour Market Liberalization and the Rise of Dualism in Europe as the Interplay between Governments, Trade Unions and the Economy. Social Policy and Administration early view (DOI: 10.1111/spol.12648).

Sulitzeanu-Kenan, R. and R. Zohlnhöfer (2019), 'Policy and Blame Attribution: Citizens' Preferences, Policy Reputations, and Policy Surprises', Political Behavior 41(1): 53-77.

van Kersbergen, K. (1995), Social capitalism: A study of Christian democracy and the welfare state, London: Routledge.

Voigt, L. and R. Zohlnhöfer (2020), 'Quiet Politics of Employment Protection Legislation? Partisan Politics, Electoral Competition and the Regulatory Welfare State', The ANNALS of the American Academy of Political and Social Science 691(1): 206-222.

Walter, S. (2010), 'Globalization and the Welfare State: Testing the Microfoundations of the Compensation Hypothesis', International Studies Quarterly 54: 403-426.

Wenzelburger, G. and R. Zohlnhöfer, (2020), Bringing Agency Back Into the Study of Partisan Politics. A Note on Recent Developments in the Literature on Party Politics. Party Politics online first (DOI: 10.1177/1354068820919316).

Zohlnhöfer, R. (2003), 'Partisan Politics, Party Competition and Veto Players: German Economic Policy in the Kohl Era', Journal of Public Policy 23: 123-156.

Cite this article: Zohlnhöfer R and Voigt L (2021). The partisan politics of employment protection legislation: Social democrats, Christian democrats, and the conditioning effect of unemployment. European Political Science Review 13, 331-350. https://doi.org/10.1017/S1755773921000114 